\title{
Climatic Analysis of a Haveli in Shekhawati Region, Rajasthan
}

\author{
Madhvi Chulet ${ }^{1}$ and Chirag Kumar ${ }^{2}$ \\ ${ }^{1}$ Student, School of Architecture and Design, Faculty of Design, Manipal University Jaipur, India \\ ${ }^{2}$ Department of Faculty of Architecture and Design, Manipal University, Jaipur, India
}

\begin{abstract}
Background/Objectives: The havelis of Shekhawati region, Rajasthan stand evidence of the glorious history of the land and rich cultural heritage of the state. These havelis are majorly known for their fresco paintings and building envelope in a semi-arid region. However, the havelis of Fatehpur town in Shekhawati region are threatened. They are either demolished or handed over to the ignorant new owners or they are abandoned or left at the mercy of poor care take cares. The negligence of these will lead to the extinction of this rich cultural heritage of Shekhawati region, Rajasthan. Methods/Statistical analysis: Haveli climate analysis in Shekawati, Rajasthan, and find out manual cooling technology. Findings: This paper will be primarily focusing upon a climatic analysis of a haveli of Shekhawati region. This shall also analyse proportion of spaces and the spatial organization with respect to controlled light, heat ad dust, exterior walls, small openings, courtyards, materials and construction techniques catering to a typical desert climate. Improvements/Applications: Use of such techniques not only reduces the dependence on artificial means of comfort but also at the same time make the building energy efficient.
\end{abstract}

\section{Index Terms}

Havelis, Heritage, Climatic Analysis, Building Envelope, Fresco Paintings, Shekhawati region

\footnotetext{
Corresponding author: Madhvi Chulet

madhvi567@gmail.com

- Manuscript received April 30, 2018.

- Revised June 6, 2018; Accepted June 10, 2018.

- Date of publication June 30, 2018.

(c) The Academic Society of Convergence Science Inc.

2546-1583 $\odot 2017$ IJEMR. Personal use is permitted, but republication/redistribution requires IJEMR permission.
} 


\section{INTRODUCTION}

The term Haveli denotes a private residence of traders and merchants of Rajasthan. In Rajasthan havelis are widely seen in the areas of Jaisalmer, Shekhawati region, Marwar and other districts where the traders used to dwell. The Persian origin of this word means "an enclosed place. where the size of openings on outer face of buildings help to cut out harsh sun and hot winds and helps to enhance the privacy. Narrow flights of steps led to upper floors. Cusped arch, foliated columns and vegetal motifs decorated the facades are some of the elements that help the havelis to be energy efficient.

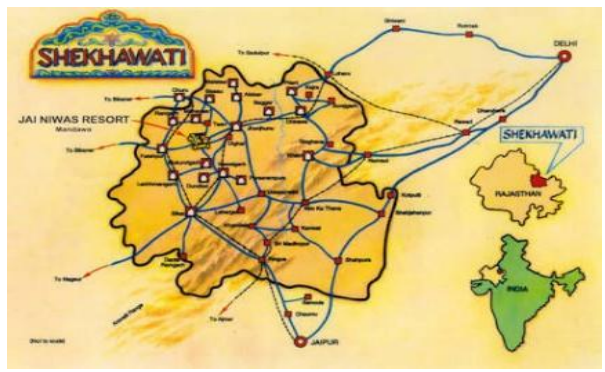

Fig. 1. Shekhawati region in Rajasthan

The havelis of Shekhawati region are known for their frescos paintings depicting mythological and historical themes. The built form of havelis depended upon the size of family.

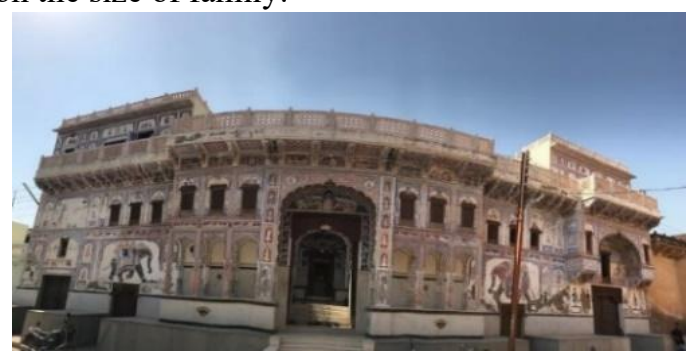

Fig. 2. Exterior of Goenka Haveli

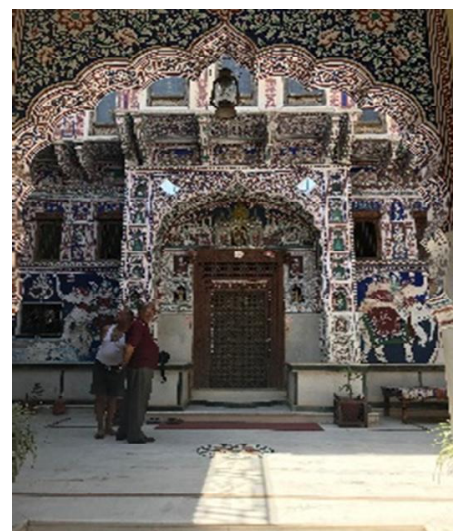

Fig. 3. Inner courtyard of Goenka Haveli

\section{Climatic anAlysis}

\section{A. Orientation}

- The haveli is oriented to maximize benefits from cooling breezes in hot weather and shelter from undesirable winds in cold weather.

- It is designed to least exposure to east and west winds to reduce heat gain and so longer side faced the north and south keeping the heat gain of the building to the minimum.

- Streets outside the haveli is to the northsouth with tall buildings on both sides to cut off the sun.

\section{B. Zoning}

- The zoning of haveli is efficient and according to the need of user. There is a clear segregation of the private, semi private and the public spaces.

- This is done to keep business related activities away from the household chores and privacy of the family.

\section{PLAN OF GOENKA HAVELI}

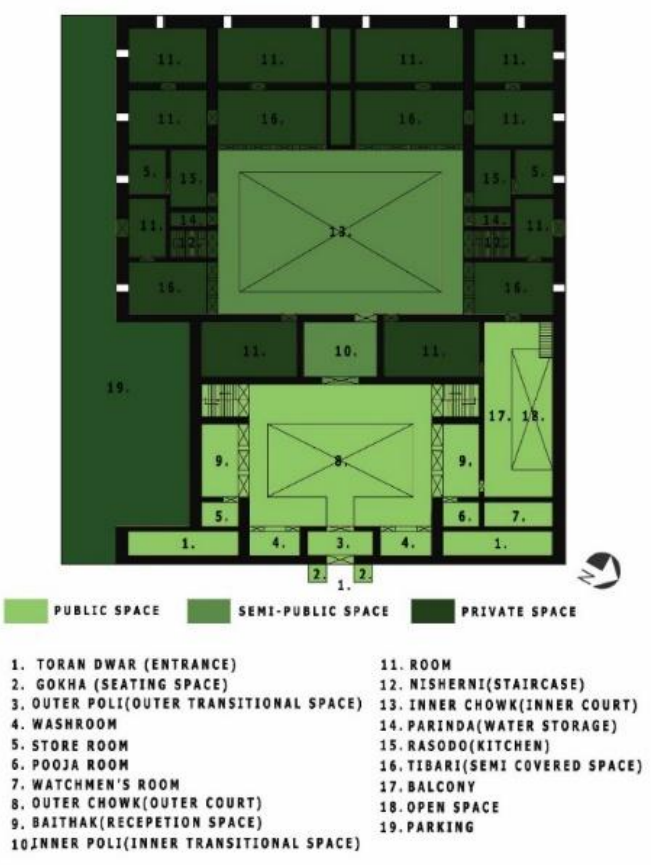

Fig. 4. Plan Zoning of haveli

\section{Entry \& Exits}

One main entry and exit of the haveli to make it secure. It also has, service entries to the rear of the private courtyard of the haveli. 


\section{Building Envelope}

\section{PLAN}

- Open plan interiors to promote natural cross ventilation, use of louvered doors, and jump ducts.

- Long narrow building floor plan that helps in maximize cross ventilation.

\section{PLAN OF GOENKA HAVELI}

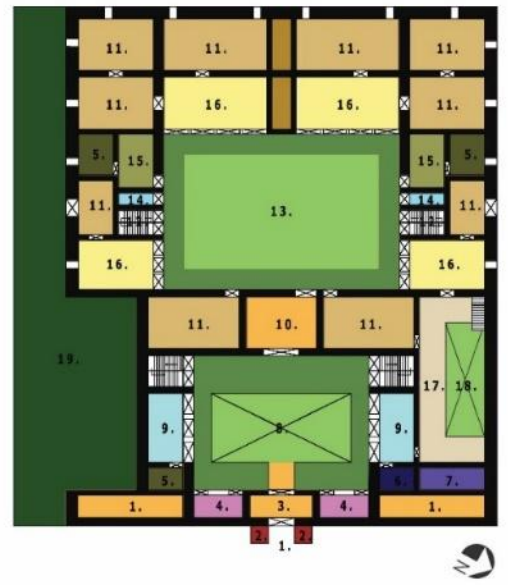

1. toran owar (entrance) . GOKHA (SEATING SPACE) 4. WASHROOM

5. STORE ROOM
6. POOJA ROOM

6. POOJA ROOM

8. OUTER CHOWK(OUTER COURT)

9. BAITHAK(RECEPETION SPACE

10INNER POLI(INNER TRANSITIONAL SPACE)

11. ROOM

2. NISHERNi(STAIRCASE)

14. PARINDA (WATER STORAGE)

15. RASODO(KITCHEN)

16. TIBARI(SEMI COVERED SPACE) 17. BALCONY 18. OPEN SPACE

Fig. 5. Spaces in haveli

\section{WALLS}

- Internal courtyard is designed with building mass all around it, leading to induced ventilation, lowering of temperatures by convective cooling and natural lighting.

- The surrounding walls rise to $600 \mathrm{~mm}$ and there are overhangs of $152 \mathrm{~mm}$ wide on four sides, protecting that side from excessive solar exposure.

\section{FENESTRATIONS}

- Windows overhangs or openable sunshades reduce or eliminate air conditioning.

- Traditional passive techniques used in haveli like enclosed well shaded courtyards, with a small fountain to provide windprotected microclimates.

- The haveli has high mass constructions with small recessed shaded openings, openable for night ventilation to cool the mass.

\section{ROOF}

- Flat roofs with light colors helps in windows oriented towards prevailing breezes and well shaded due to which there is good natural ventilation.

- Light color building materials and cool roofs to minimize conducted heat gain.

\section{E. Courtyard}

- Courtyard is a more sustainable form of housing as it allows constant contact with the natural world- sun, fresh air and water.

- They performed better function in terms of efficiency in built potential and day-lighting.

- The placement of the central courtyard, its size and orientation is the most important aspects of the design as the courtyard plays a major role in the modification of the harsh summer and winter environment by providing a comfortable microclimate for the haveli.

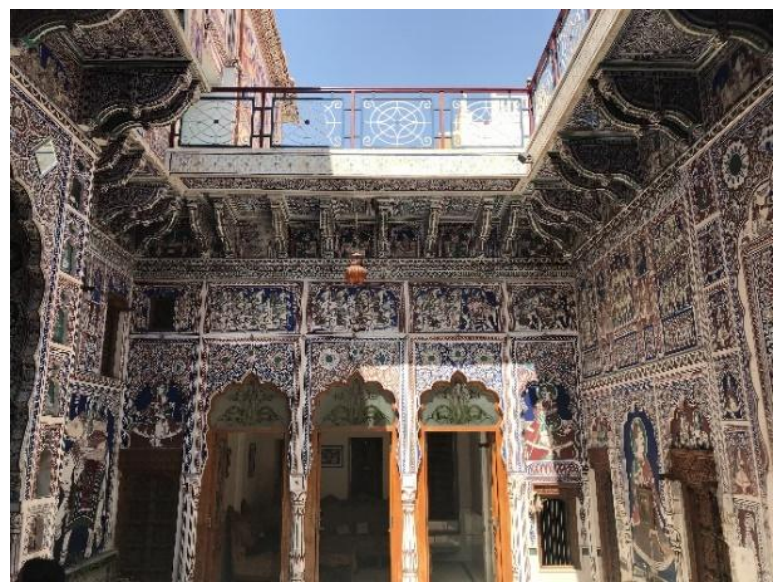

Fig. 6. light and ventilation in the courtyard

- They are designed to have street interaction, the haveli has a platform next to entrance door and before entering to outer courtyard, for people to have sitting on the platform.

- Inner courtyard has less perforation because it was mainly for female of the house.

- The courtyard form is dominant in the tightly packed traditional architecture.

- By avoiding exposure of individual external walls, an optimum indoor temperature is achieved in both summers and winters. 


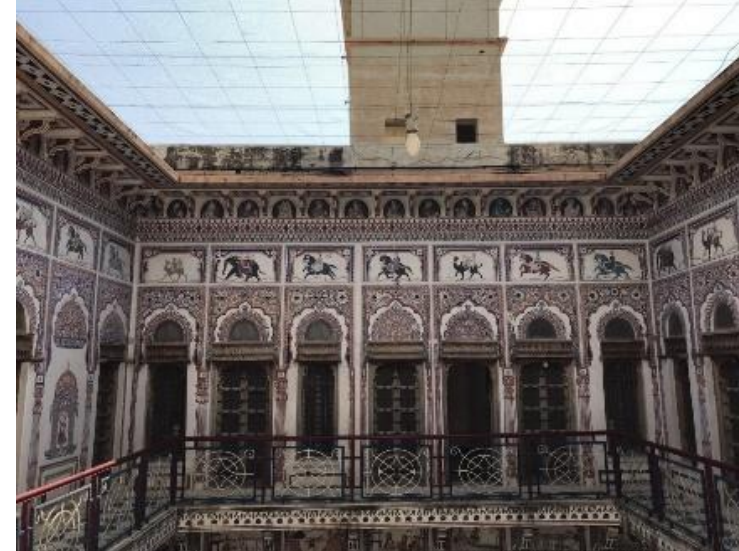

Fig. 7. wind tower in haveli

- Courtyard is laid in a SE- NW orientation. This is about $40^{\circ}$ off the cardinal points, which exposes the NW wall to morning sun. The NE wall also gets the sunlight from early morning until midday, after which the sun penetration is largely controlled by the takht on the NW side. The lower winter sun is able to penetrate the courtyard (NW, NE $\&$ SE sides) until midafternoon i.e. 4 pm

- The Inner Courtyard of the Havelli is $13500 * 9000 \mathrm{~mm}$ in Length And Breadth.

- The courtyard is oriented 45 degrees from the prevailing wind which maximizes wind in the courtyard and cross ventilation through the building keeping the courtyard cool.

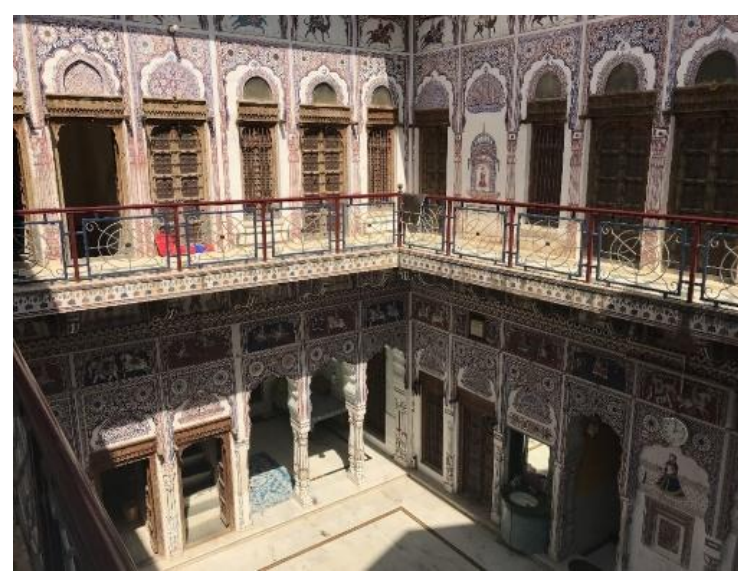

Fig. 8. Semi open spaces in a courtyard

- The courtyard forms a rectangle and occupies nearly $30 \%$ of the total haveli area.

- Size of Courtyard is designed keeping in mind of the gatherings which would take place in courtyard.

- The courtyard acts as dust controller in desert climate.

- The opening of rooms of haveli is opened in courtyard so as to avoid dust storm outside.
- The paving materials of courtyard collects the dust and regular cleaning is done.

- Shaded Colonnades and Semi Open Areas are given outside the rooms and so the courtyard are receives fairly good light and natural ventilation.

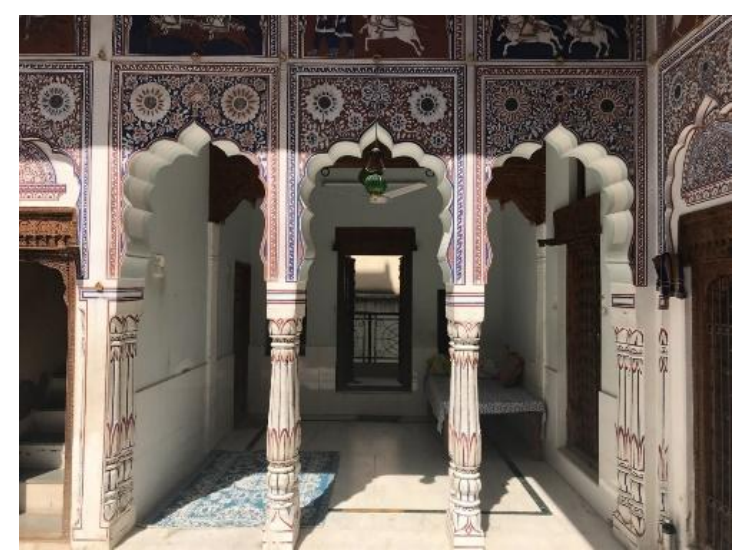

Fig. 9. Shaded colonnades

\section{F. Art Forms}

- Fresco paintings

- Mural Painting

- Wood Carving

- Patra Work

- Stone carving

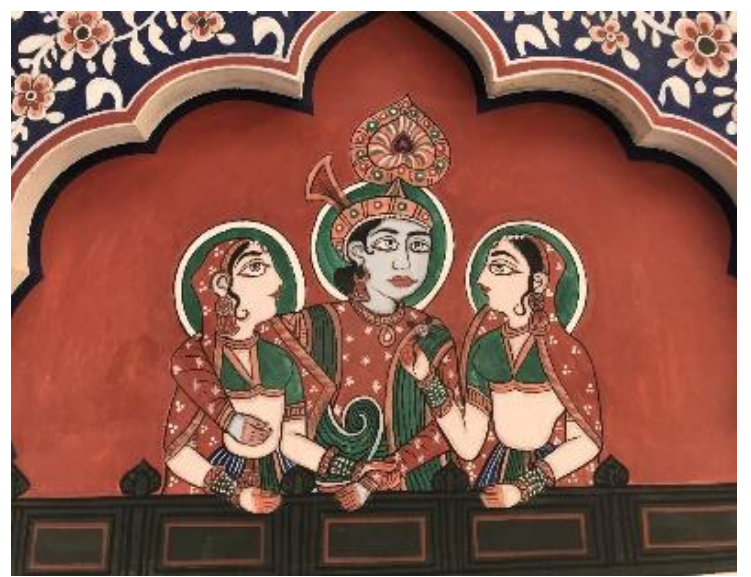

Fig. 10. Fresco painting 


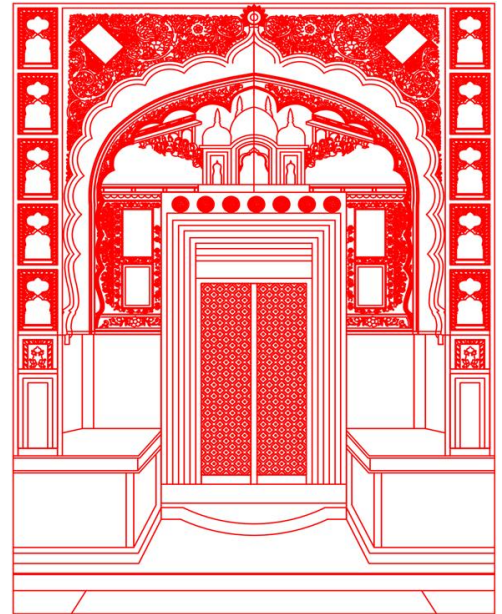

Fig. 11. Detailing on doors of haveli

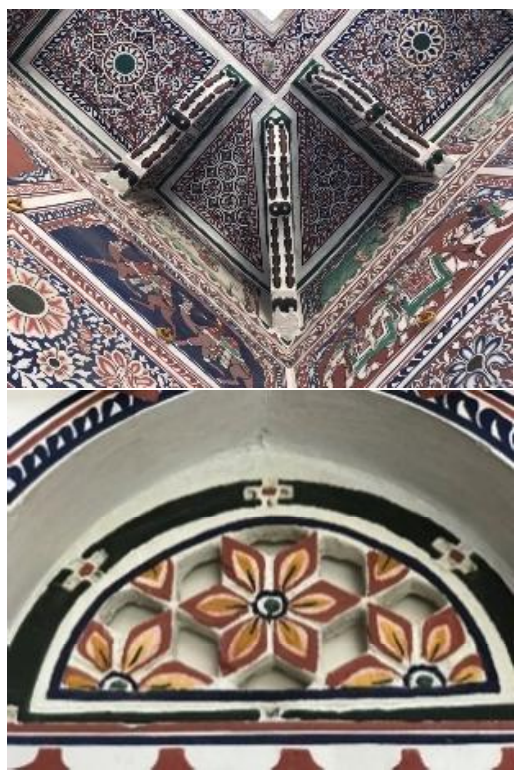

Fig. 12. Stone carvings

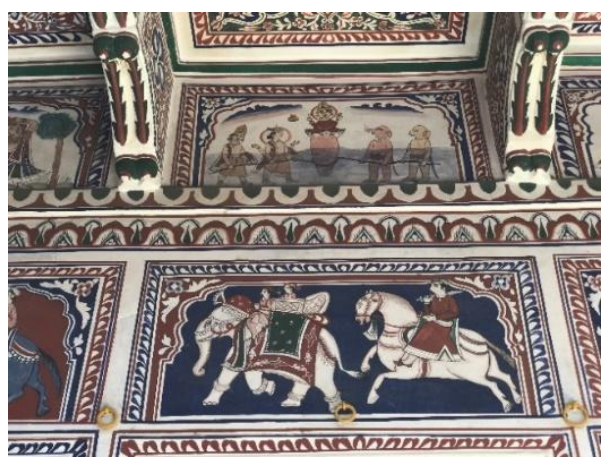

Fig. 1. Fresco painting in Goenka Haveli

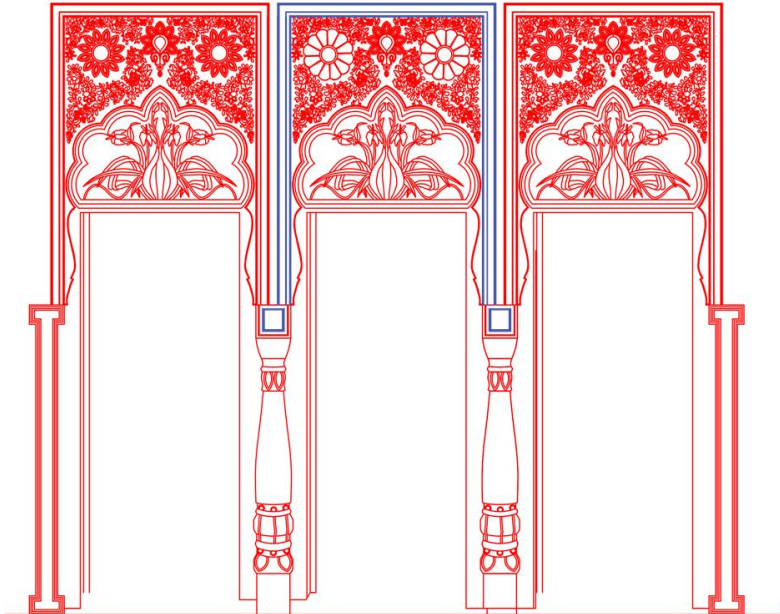

Fig. 14. Mural paintings on shaded colonnades

\section{Passive CoOling TECHNIQUES}

\section{A. Building Envelope}

- Compact settlement plan, introvert buildings.

- Perimeter/Area ratio shall be less.

- Shaded courtyards to facilitate ventilation and lower daytime temperatures inside.

- Less of exposed surfaces and shading of all the exposed surfaces.

- Least exposed to east and west orientation.

- Appropriate shading to openings using thick wooden shutters or materials with low thermal capacity.

- Bottle neck openings or Jalis that enhanced ventilation and reduced temperatures.

- Fenestration are towards oriented north.

- Shading devices such as louvers or Jharookhas to shade openings from sun.

- Heavy thermal mass of structure.

- Insulation layer not directly exposed to the sun.

- Light colors on exterior.

\section{B. Construction technologies}

- Heavy building envelope

- 1'6" thick locally available stone plastered with lime. Columns - are either assembled with laterite stone or are monolithic with timber type joints.

- Flat roofs with insulation layer - roof is also 1' 6" thick, double layered with a layer of stone veneer with lime mortar on it.

- Lime, jaggery and hesian mixed together in the roofing plaster.

- A layer of inverted clay pots is then placed on it with a layer of lime mortar " nished 
with reflective broken pieces of porcelain which reflects most of the sunlight.

\section{Materials}

- Stone used along with lime mortar as lime mortar allows to keep lower temperatures inside the building and stone helps in creating time lag due to high thermal capacities.

- The haveli was a result of a unique combination of material availability and the skilled labour needed to execute construction.

- Materials having high thermal capacity and low conductivity for structures are used.

- As the landscape of Shekhawati, with its hills, made transporting materials difficult, material use centered, for the most part, on things locally available.

- There are a few major materials that play into the construction of the haveli, within the walls, the doors and beams and the architectural elements throughout the haveli.

- There are three materials that are found in the walls, brick prepared from locally sourced red clay, stone-fragments and dhandhala, which was a greyish lump of hardpan.

- The major aspect of haveli construction is timber, and though there is greenery and trees in Shekhawati, much of the wood is not suited for construction; rather the haveli was the result of a combination of two types of woods.

\section{CONCLUSION}

Havelis are those traditional buildings of the past that provide the rich experiences of the past and respond to the climate and society of the place in terms of material selection, spatial-organization, constructions techniques and use of passive design features.

Also, the haveli is a great example of how use of appropriate materials, construction techniques and passive design elements can give comfort from the environment in the indoors.

Use of such techniques not only reduces the dependence on artificial means of comfort but also at the same time make the building energy efficient.

\section{ACKNOWLEDGMENT}

Gratitude of thanks to our mentors, Prof.(Dr.) Madhura Yadav and Ar. Md. Nauman Nizamuddin for their kind concert for allowing to work on the topic of "Havelis of Shekhawati Region", and helping in the materialization of this topic successfully.Also Faculty of Design, Manipal University, Jaipur for giving me permission to commence this topic in the first instance, to do the necessary research work and to use department data.

\section{REFERENCES}

[1] Upadhyaya, V. (2017). Transformation in Traditional Havelis, a case of walled city. Jaipur, Rajasthan.

[2] Agrawal, A. "Architecture of Shekhawati-Aesthetic prevails", Kerala, India: MES School of Architecture.

[3] Khanna Jain, S. (May-Jun 2003). "Haveli Spaces- an anthropological interpretation"

[4] Shrivastava, U. (Nov-Dec 2003). "Shekhawati-Hues and Rues"

[5] Sinha Roy, A. (Jan 2017). "Features of planning- Shekhawati haveli". Retrieved from http://talkarchitecture.in/featuresplan-shekhawati-havelli/

[6] Srivastava U. (2009). Indian heritage passport programme on the merchants' trail in Shekhawati. Retrieved from http://unesdoc.unesco.org/images/0018/001812/181292e.pdf

[7] Jain, S. (2011). Indian heritage cities network: walking into the microcosm of Jaipur. Retrieved from http://unesdoc.unesco,org/images/0019/001921/192113e.pdf

[8] Ramgarh Shekhawati. Retrieved from http://www.ramgarghshekhawati.com/haveli.html

[9] Charan, G. (2008). Shekhawati havelis. Retrieved from http://www.researchtrend.net/ijet/pdf/57\%2073.NCUEMI_/ Garima\%20Charan.pdf

[10] Havelis of Shekhawati(2018) http://www.shipsupply.bike/pdffile/shekhawati the havelis of_the_merchant_princes. 